\title{
The Atlee School Question: The Effects Of School Consolidation In Rural Alberta
}

Steven Boddington, PhD., Athabasca University, Canada

\begin{abstract}
In the mid-1960s, a bitter dispute broke out between parents in the Atlee-Jenner School District in Southern Alberta Canada, and the Medicine Hat School Board over the bussing of children for the first time to a new school a long distance away. The move was precipitated by the consolidation of several smaller school districts and the subsequent closing of the local school. The parents' argument was that the road by which the bus was to travel was in an unfinished state and was dangerous. However, the conflict is illustrative of a much deeper issue. An argument might be made that this dispute illuminated a much larger crisis in rural life on the prairies. It may represent, as a case study, the problems and difficulties involved in a shift from rural life, with its unique sorts of interpersonal relationships built on the strength of local community and co-operative spirit, to a much more urbanized and structured existence. As the Great Depression had shown, the myth that you could always go back to the farm for some measure of economic security had been dispelled. However, one's control over the education of one's children, and thus the inculcation of appropriate values and beliefs, after having been first of all, institutionalized with universal public schooling (both Protestant and Roman Catholic), had been, at least up to this point, largely a local concern, under a central authority (Ministry of Education). School divisions on the prairies had been relatively small and numerous, for practical reasons, such as transport and regular attendance. Gradually, these small divisions came to be replaced by larger administrative units, thus threatening the perceived control and familiarity of local communities. The other half of the equation in this dispute was the reaction of the Deputy Minister at the time, W.H. Swift. Swift could empathize with the basic issues in play, having strong rural roots himself. Deputy Minister of Education, W.H. Swift was also one of the last to hold that position rising up through the ranks of the education system, from teacher to school inspector to academic. Swift had earned a Ph.D. at an early age, and rose quickly through the ranks of the civil service, learning his job under the tutelage of G. F. McNally. Swift and McNally represented a tradition in the Department, having earned their positions through experience and hard work. As such, they might be viewed as self-made moral exemplars, leaders who could be viewed as role models by the rank and file. This article seeks not only to illustrate how Swift actually functioned in his role as Deputy Minister in times of crisis and high public visibility, but also to show how he reacted when confronted with moral decisions. The Atlee case, taking place between the years 1955 and 1965, serves as an example of the controversy which had developed in many areas as small rural schools were closed as a result of the divisional amalgamations begun by the Social Credit Government before the Second World War. On a wider scale the issues embodied in the dispute also reflect a changing rural landscape. Just as the small family farm was under corporate pressure, so it was with the local school. These economic and administrative transformations brought with them social and cultural changes as well. Although the case was one of the last examples of this kind, it was certainly one of the most bitterly contested.
\end{abstract}

\section{INTRODUCTION}

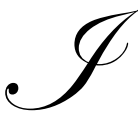
n 1958, the parents of children who had been attending the Atlee school, a tiny community sixty miles northwest of Medicine Hat, Alberta, Canada, had withheld them from attending since receiving notice that they were to be bussed to Jenner, 19 miles away. The dispute soon escalated into a province-wide issue involving school district consolidations and the right of parents to choose where to send their children to school. An argument might be made that this dispute was illustrative of a much larger crisis in rural life on the prairies. It may 
represent, as a case study, the problems and difficulties involved in a shift from rural life, with its unique sorts of interpersonal relationships built on the strength of local community and co-operative spirit, to a much more urbanized and structured existence. As the Great Depression had shown, the myth that you could always go back to the farm for some measure of economic security had been dispelled. However, one's control over the education of one's children, and thus the inculcation of appropriate values and beliefs, after having been first of all, institutionalized with universal public schooling (both Protestant and Roman Catholic), had been, at least up to this point, largely a local concern, under a central authority (Ministry of Education). ${ }^{1}$ School divisions on the prairies had been relatively small and numerous, for practical reasons, such as transport and regular attendance. Gradually, these small divisions came to be replaced by larger administrative units, thus threatening the perceived control and familiarity of local communities.

The other half of the equation in this dispute was the reaction of the Deputy Minister of Education for the Province of Alberta at the time, W.H. Swift. Swift could empathize with the basic issues in play, having strong rural roots himself. . Swift was also one of the last to hold that position rising up through the ranks of the education system, from teacher to school inspector to academic. Swift had earned a Ph.D. at an early age, and rose quickly through the ranks of the civil service, learning his job under the tutelage of G. F. McNally. Swift and McNally represented a tradition in the Department, having earned their positions through experience and hard work. As such, they might be viewed as self-made moral exemplars; ${ }^{2}$ leaders who could be viewed as role models by the rank and file.

This article seeks, to show how the Atlee case, taking place between the years 1955 and 1965, serves as an example of the controversy which had developed in many areas as small rural schools were closed as a result of the divisional amalgamations begun by the Social Credit Government before the Second World War. On a wider scale the issues embodied in the dispute also reflect a changing rural landscape. Just as the small family farm was under corporate pressure, so it was with the local school. These economic and administrative transformations brought with them social and cultural changes as well. Although the case was one of the last examples of this kind, it was certainly one of the most bitterly contested. It also serves to illustrate how the administration of the time, under the leadership of W.H. Swift, functioned in times of crisis and high public visibility

By the time of the dispute, Swift was firmly entrenched at the top of the educational hierarchy of the Province with his bureaucratic and educational credentials fully established. He had, by this time, been Deputy Minister for nearly fifteen years and had perfected the art of being able to detach himself from the confusion of the moment and to pinpoint, with a clarity derived from, as the nineteenth century British scholar Henry Taylor so aptly put it, "executive experience, ${ }^{13}$ the essence of a given problem.

In looking back over his tenure as Deputy Minister, Swift was inclined to point to the elimination, over a relatively short time, of the one-room school and their replacement by centralized schools, as being one of the most significant occurrences during his regime. This included, of course, the wholesale bussing of farm pupils. Swift recalled that:

The formation of school divisions, the aggregation of 50 or more one-room schools, had been almost entirely completed during the regime of G.F. McNally. While there was then an over-all Board and administration, they continued to operate the existing one-room schools. There were probably over 3000 such schools when I became Deputy Minister. ${ }^{4}$

By the time Swift left office, in 1964, there were practically no one-room schools left in Alberta, "despite the frequent opposition of local boards and communities who felt that their local identity and authority were being

\footnotetext{
${ }^{1}$ John W. Chalmers, Schools of the Foothills Province: The Story of Public Education in Alberta, Toronto: University of Toronto Press, 1967), 283. This was a plan, which had been adapted from an idea originally put forward by the Social Credit government's predecessor, the United Farmers of Alberta, in particular, Education Minister Perren Baker, but never acted upon.

${ }^{2}$ See Steven Boddington, "Education From The Top Down: A Biography of W.H. Swift", (Edmonton: University of Alberta, 1998).

${ }^{3}$ Henry Taylor, The Statesman, (London: Longman, Rees, Orme, Brown, Green and Longman, 1836), xvii.

${ }^{4}$ W.H. Swift, unpublished memoirs, n.d.
} 
undermined." ${ }^{5}$ The Department Of Education was favourable to these developments but did not attempt to impose them. ${ }^{6}$ One such controversial attempt at forced centralization was the Atlee-Jenner case.

\section{THE ATLEE - JENNER SCHOOL DISPUTE}

In September of 1958, a Calgary Herald headline read: "The Battle of Atlee Continues and the Children Stay at Home. ${ }^{77}$ Invoking every southern Albertan ranching icon from broncos and lassos to heartbroken young buckaroos, the rather maudlin piece went on to relate that:

Seven-year-old Danny Garrlock is a big boy. He derives the most delight when his cowboy dad allows him to saddle a horse and accompany him on range forays in his job as community lease rider for the Alberta Government. But Danny cried September 4. His tears fell unashamedly in his mother's lap that afternoon as he related the message given him by school teacher Mrs. Irene Walsh. School was finished at Atlee. Acting on instructions from Medicine Hat School Division No. 4, the one-room school at Atlee had to close at once. Danny was fashioning a lasso Wednesday while thousands of other Alberta children were learning the three R's. A car drew up to the small Garrlock ranch home and 'dad's helper' watched in silence as a well-dressed man handed Danny's father a blunt legal notice. In one way it solved the youngster's educational difficulties. In another it made the situation more acute. ${ }^{8}$

Parents of children who had been attending Atlee school, a tiny community sixty miles northwest of Medicine Hat, had withheld them from attending since receiving notice that they were to be bussed to Jenner, nineteen miles away. Danny's father, the paper pointed out, was one of three Atlee residents served with a warning to have his children attend school at Jenner, or face prosecution under the School Act. They were given five days in which to act. ${ }^{9}$

The Herald went on to note that Atlee school chairman, George Howe summed up the feelings of all three parents when he pointed out that:

I've lived in this district all my life. I know what winter can do to these roads and time after time I've had to resort to horseback to travel the three miles into Atlee. Sure the divisional board can sit in Medicine Hat and tell us what to do but making us do it is another thing. We know this district a lot better than they. ${ }^{10}$

All the parents, according to the paper, stated that they were willing to face a jail term rather than spending countless winter days in anxiety over the safety of their little ones. ${ }^{11}$

Incredibly, the same issue had erupted the previous year when the Board of School Division No. 4 had advised Atlee parents of the Jenner plan. In similar fashion, the parents had balked at sending their children on what they considered a hazardous nineteen-mile journey over a road considered to be dangerous. At that time, the board had relented and allowed the students to continue their studies at Atlee for the remainder of the term. ${ }^{12}$

On the other side, the resolute stand of the Atlee parents was described by Ted Roll, the board chairman of School Division No. 4, as being like "B.C. Doukhobors in many ways." ${ }^{13}$ Roll stood by the board's decision and the

${ }^{5}$ Ibid.

${ }^{6}$ See Appendix "B" of W.H. Swift, Memoirs of a Frontier School Inspector in Alberta, for a discussion regarding the inevitability of the demise of the one-room school in Alberta.

${ }^{7}$ The Calgary Herald, September 8, 1958.

${ }^{8}$ Ibid.

${ }^{9}$ Ibid.

${ }^{10}$ Ibid.

${ }^{11}$ Ibid.

${ }^{12}$ The Medicine Hat News, November 2, 1958.

${ }^{13}$ The Calgary Herald, September 8, 1958. This was an obvious reference to the Sons of Freedom Sect which had gained much notoriety throughout the 1950s through a series of demonstrations and bombings. All Dukhobours for many years thereafter were painted with the same brush. See Nick Kach for more on this issue. 
notice delivered by its agent, attendance officer, Charles Vaughn, which read:

Take notice that unless within five days from the receipt by you of this notice you cause your child (or ward) to attend school, you will be liable to prosecution under the School Attendance Act. And further take notice that if within 12 months after the date of service of this notice upon you, you fail to cause the above mentioned child, or any other child of whom you have charge or control between the ages of 7 and 15 to attend school and continue regular attendance thereat, you will be liable to prosecution under the said Act without notice. ${ }^{14}$

To understand the source of this antipathy one must go back to the introduction by the Alberta Social Credit Government, in 1936, of legislation calling for the amalgamation of hundreds of smaller school districts into larger school divisions. Chalmers noted that, by 1941, a total of fifty divisions were in operation and by 1966 the total was fifty-nine. ${ }^{15}$ According to its own brochure, After Three Years, the Alberta government was mightily pleased with the results of this endeavour. It trumpeted the "increased opportunities . . . being provided for high school pupils, the better conditions under which teachers [were able to] . . carry out their duties as instructors, the improvement in the accommodation and equipment of schools, [and] . . the more harmonious relations developed among people of each community."16 These were all factors, the brochure claimed, "which . . . contributed to the growing favour with which the larger administrative unit [was] . . . being accepted by the people." 17 The publication went on to say that despite the fact that it had not lowered expenditures on education as a whole, it had "reduced the yearly cost per pupil according to both enrolment and average attendance and also the average cost per pupil for each day of attendance." 18 As well as increasing the opportunities of rural children, it went on, it had "succeeded in giving the people of the Province a larger return on their educational dollar." ${ }^{19}$

For the most part, these claims were not out of line. The divisional boards had acted to put a qualified teacher in every classroom, they had improved health services, increasingly made high school education available to every child, and equalized the school tax rates. As a further bonus, wrote Chalmers, rural children attending centralized schools "helped breakdown the hostility and suspicion with which town and country children commonly regarded each other." ${ }^{20}$

By 1940, the organization of the province into school divisions had been, for the most part, completed. It was, however, the next big advance, which caused friction. According to Chalmers:

Formation of the divisions had resulted in centralization of administration; the next logical step was centralization of instruction. ... [This] would confer unnumbered benefits. First it would make obsolete the ungraded classrooms, ... each teacher would have not more than three grades in his [or her] classroom. Better teachers could be found and retained. With large elementary schools, adequate high schools would be possible. . . The very presence of more children in a grade would introduce ... competition and emulation. ${ }^{21}$

Unfortunately, the Second World War seriously impeded progress toward these goals. Alberta's chronic shortage of teachers was exacerbated by the global conflict. This situation would continue until well after the war. That this concerned Swift is evident from his comments in the Department's Annual Report of 1946:

\footnotetext{
${ }^{14}$ Ibid. upon.

${ }^{16}$ Alberta Government, After Three Years, (Edmonton: King's Printer, 1940), as quoted in Chalmers, 288.

${ }^{17}$ Ibid., 288.

${ }^{18}$ Ibid.,288-289.

${ }^{19}$ Ibid., 289.

${ }^{20}$ Chalmers, $\underline{\text { Schools, }}$, 289-291

${ }^{21}$ Ibid., 291.
}

${ }^{15}$ Chalmers, Schools, 287. John W. Chalmers, Schools of the Foothills Province: The Story of Public Education in Alberta, Toronto: University of Toronto Press, 1967), 283. This was a plan, which had been adapted from an idea originally put forward by the Social Credit government's predecessor, the United Farmers of Alberta, in particular, Education Minister Perren Baker, but never acted 
The year 1946 must be recorded as being a most difficult and trying one from the standpoint of school administration. The continued and increased shortage of teachers has not only deprived thousands of children of a proper educational opportunity but has imposed upon school authorities ... a great burden of effort, worry and public discontent. While only 52 schools were without some sort of service at the end of the year, the superintendents reported that about 1,500 rooms were either without service or were being supplied in some makeshift or inferior manner. ${ }^{22}$

In addition to the lack of teachers, the lack of labour, equipment or supplies available to build new schools at central points, and a shortage of appropriate transport and the sometimes poor or non-existent roads, resulted in many of the planned projects being put in a holding pattern until the end of the war. Sometimes, as in the case of the Atlee Jenner dispute, the undertaking might be delayed until many years later. ${ }^{23}$ This was confirmed by Swift's last Minister of Education, R. H. McKinnon. When queried about the Jenner case, he recalled that there were:

big fusses down there, particularly in the south. They didn't want to lose their local schools. There were some of those schools that were left over by the 1950s. They just didn't want their kids bussed anywhere. What happened was we put the division in anyway but allowed the schools to sit there for a while until things sorted themselves out. ${ }^{24}$

However, by the end of 1945, Alberta's pre-war total of three thousand one-room schools had shrunk to about two thousand. Chalmers wrote that before the divisional movement could really reach maturity, there had to be points where they could centralize. These points were the town and village districts where there were already multi-room schools to serve as focus for the proposed central schools. The inclusion of these districts to the divisions was seen, therefore, as essential. For the most part these inclusions offered enough benefits to each side that "ultimately about two hundred agreements were completed." 25

According to Chalmers, the transition from district to divisional control did not always go as smoothly as the Department would have liked. "In many cases, the district was unwilling to surrender control of its school system, expressing its aversion either through the action of its board or through a plebiscite." ${ }^{26}$ However, by 1964, there were only seven independent consolidated districts left in the Province. Two independent village public school districts still existed, and fifteen town districts. ${ }^{27}$ It is from within this milieu, then, that the Atlee case can best be understood.

The first mention of the Atlee dispute, according to the documentary evidence, appears to be a letter, dated March 26, 1956, from Mrs. George Howe, wife of the Atlee School Chairman, addressed to "The Department of Education." The letter simply inquired as to whether or not people could be forced into a centralized school, "seventeen or twenty-five miles from our present school?"28 The letter went on to explain that the majority of residents of this "isolated" area were quite happy with their present school. ${ }^{29}$ Mrs. Howe closed with a request for a copy of the "School Act." ${ }^{30}$ Since no other correspondence appears until the 1957 school year, it must be assumed that things remained as they were for the balance of the year.

\footnotetext{
${ }^{22}$ Annual Report of the Department of Education, Province of Alberta, 1946. P.A.A. Acc. No. 68.232. 8.

${ }^{23}$ In fact, a similar dispute involving the same Medicine Hat School Division and the residents of Buffalo was still raging as late as 1963. In this case it was over the busing of pupils then attending Buffalo school to Blindloss, twenty miles distant. Correspondence: April 3, 1963, from the Concerned Parents of Children Attending Buffalo School to The Rt. Honorable E.C. Manning, Cypress Hills School Divisional Records, Files 38-141, Calgary Glenbow Archives.

${ }^{24}$ Personal interview with R.H. McKinnon, former Minister of Education for the Province of Alberta, 1964-1967, January 26, 1998.

${ }^{25}$ IChalmers., 292.

${ }^{26}$ Ibid., 292.

${ }^{27}$ Ibid., 293.

${ }^{28}$ Correspondence from Mrs. George W. Howe to The Department of Education, March 26, 1956. Cypress Hills School Divisional Records, Files 138-141, Calgary - Glenbow Archives.

${ }^{29}$ It should be noted that the number of families involved in this affair never numbered more than five, with a population of twelve school age children. Correspondence, A.T. Shand, Secretary Treasurer, Medicine Hat School Division No. 4, to "All parents in the Atlee School Attendance Area", September 26, 1958. Cypress Hills School Divisional Records, Files, 138-141, Calgary-Glenbow Archives.

${ }^{30}$ Mrs. G.R. Howe to Department of Education, March 26, 1956.
} 
In 1957, however, things became more serious. Atlee parents balked at the Divisional Board's decision to close down their school. According to a communication addressed to J.W. Chalmers, then Swift's Assistant Director of School Administration at the Department of Education, the board's reasons for this action were the following:

a. The move was a part of the planned centralization of the school facilities in the Jenner area.

b. The present enrolment at Jenner is only 20 with two qualified teachers on staff.

c. The Jenner school is a new, fully modern building, and no opposition to the vanning was registered until construction was almost completed.

d. The van driver has purchased a new 4-wheel drive van for the route and has been given a three-year contract.

e. The Special Areas Board promised to carry out road improvements to carry out vanning.

f. Correspondence courses were not acceptable to the Atlee residents.

g. Other centralizations might be adversely affected by a reversal of the Board's decision at Atlee. ${ }^{31}$

Three days earlier the parents of Atlee had outlined their objections to the proposed move in a letter to the Division. They contended that they were worried about the "danger and inconvenience of sending the children 53 miles each way to and from the school at Jenner." ${ }^{32}$ The letter went on to say that "although this is a main road for that part of the country it has always been recognized as a dangerous highway, there being several blind hills and bad curves." ${ }^{33}$ The communication went on to describe how several accidents had occurred on the road in the past months, that it became particularly hazardous in winter, and that there were only three houses on the entire route and no telephone in case of emergency. ${ }^{34}$ In view of this, the letter went on,

we are sure that the mothers of some of the children will refuse to allow the pupils to attend on days when the weather outlook is bad. Perhaps the parents have no legal right to do so but it is almost a certainty that it will be done, and we feel that any plan of the Board which would result in such a situation should be carefully reconsidered. ${ }^{35}$

By the end of October, 1957, the crisis had reached the point where Swift became involved. A meeting of all divisional board members was held at the Palliser Hotel in Calgary on Wednesday, November 6. A circular pointed out that Swift (mistakenly referred to as the Minister!) and J.W. Chalmers wanted to meet with the full board, "in connection with recent happenings concerning the non-attendance at school of pupils in the Atlee area." 36 No record exists regarding the meeting itself but the result, according to the Medicine Hat News, was that apparently "the board finally relented" and permitted the children to complete their studies at the Atlee school for the remainder of the year. ${ }^{37}$

Just prior to the beginning of the 1958 school year, the board of School Division no. 4 once again informed Atlee parents of the provision of "school bus service for the pupils of Grades I to IX, inclusive ..., so that they may be

\footnotetext{
${ }^{31}$ Correspondence, A.T. Shand, Secretary Treasurer, Medicine Hat School Division to Dr. J.W. Chalmers, Assistant Glenbow Archives.

${ }^{31}$ It should be noted that the number of families involved in this affair never numbered more than five, with a population of twelve school age children. Correspondence, A.T. Shand, Secretary Treasurer, Medicine Hat School Division No. 4, to "All parents in the Atlee School Attendance Area", September 26, 1958. Cypress Hills School Divisional Records, Files, 138-141, Calgary-Glenbow Archives.

${ }^{31}$ Mrs. G.R. Howe to Department of Education, March 26, 1956.

Director of School Administration, Department of Education, October 11, 1957. Cypress Hills Divisional Records, Calgary-Glenbow Archives.

${ }^{32}$ It is of interest that in all other accounts concerning this issue, the mileage adds up to 38. Correspondence from The Parents of Atlee to The Chairman, Divisional Board, Medicine Hat School Division No.4, October 8, 1957. Calgary-Glenbow Archives.

${ }^{33}$ Ibid.

${ }^{34}$ Ibid.

${ }^{35}$ Ibid.

${ }^{36}$ Circular addressed to All Divisional Board Members from A.T. Shand, Secretary Treasurer, Medicine Hat School Division No. 4., October 30, 1957. Cypress Hills Divisional Records, Calgary-Glenbow Archives.

${ }^{37}$ The Medicine Hat News, August 28, 1958.
} 
able to attend Jenner school." 38 The letter concluded with the board's statement that it did "not intend to operate the Atlee school" and that "two qualified teachers" had been engaged to operate the school at Jenner. ${ }^{39}$ It further stated that if the present Atlee teacher wished to transfer to Jenner, "three rooms would be operated there. ${ }^{40}$ Once again, the Atlee parents protested.

Almost simultaneously the press picked up on the story and came down resoundingly on the side of the Atlee residents. The front page headline in the Medicine Hat News read: "Atlee Issue Flares: Parents Balk at School Bus." 41 According to the article, James Walsh, the secretary of the Atlee School Board stated that they had been promised the previous year, when the school had re-opened, that "no further action would be taken for at least a year until road repairs were made." 42 Moreover, Walsh continued, at a meeting of School Division No. 4 at Blindloss, in February of 1958, they had been "assured the matter would not come up again until June 1959."43 He went on to state that they had "heard nothing more about it until August 21, when a notice was posted . . . advertising for school bus tenders and we realized they were going to go ahead with it." ${ }^{44}$ Walsh concluded by stating that:

It might be a different matter if the road had been repaired as promised, . . but conditions there are as bad as ever ... and our stand is still the same. We will not send our children to school in Jenner until safe transportation is provided. ${ }^{45}$

Work on the road was not scheduled to begin until September 1 , of that year. ${ }^{46}$

On behalf of the Board, Secretary Shand stated that:

Atlee residents should have been well aware that this was going to happen . . . The agreement reached last November was effective only for the remainder of the school year... . We will provide our own bus service and the roads will be repaired in due course. This is merely a continuation of last year's plans. ${ }^{47}$

Shand held that the Atlee parents had a "weak argument" with regard to the nineteen-mile distance the children would have to travel, as "many youngsters have to travel further." 48 To this, another board member added that the road in question was "no worse than any other average district road."49 Shand concluded by stating that there would be "a possibility of prosecution if they [the Atlee parents] keep their children out of school."

The sparring through the press carried on for nearly two months with neither the Board nor the Atlee parents willing to budge. By now, the dispute had come to the attention of the Calgary papers. The Calgary Herald portrayed the affair as a guerrilla war being fought by the residents of Atlee against the overwhelming might of the Department of Education and their agents, the Board of Medicine Hat School Division No. 4. In October of 1958, the Herald summarized the issue in the following manner:

This tiny community, sixty miles northwest of Medicine Hat, shows every sign of continuing its war against the forces of the Alberta Department of Education. Parents who have been keeping their children out of school for the past two

\footnotetext{
${ }^{38}$ Correspondence to "All Parents in the Atlee School Attendance Area" from Medicine Hat School Division No. 4, August $29,1958$. Cypress Hills School Divisional Records, Calgary-Glenbow Archives.

${ }^{39}$ Ibid.

${ }^{40}$ Ibid.

${ }^{41}$ The Medicine Hat News, August 28, 1958.

${ }^{42}$ Ibid.

${ }^{43}$ Ibid.

${ }^{44}$ Ibid.

${ }^{45}$ Ibid.

${ }^{46}$ Ibid.

${ }^{47}$ Ibid.

${ }^{48}$ Ibid.

${ }^{49}$ Ibid.

${ }^{50}$ Ibid.
} 
months [appear] ... determined to keep on doing so until the war is won ... . Lymon Davis who owns a bus and holds a contract to transport Atlee area youngsters to the new school, makes the trip between Atlee and Jenner twice daily with no more than one young passenger picked up six miles outside of Jenner. ${ }^{51}$

To make matters worse for the Board, the paper reported that on the night of October 2, the school bus carrying the driver and a teacher, returning from a meeting, was involved in an accident resulting in both men being hospitalized and the bus being put temporarily out of commission. According to the Herald, it was "not known how the accident happened except that the bus went out of control and left the road," ${ }^{52}$ the same road earlier described by the Atlee parents as "dangerous" in both summer and winter.

By late October, the Chairman and Trustees of School Division No. 4 were being accused of "bureaucratic bungling." ${ }^{53}$ The Medicine Hat News also pointed out that the district trustees were "permitting a waste of the taxpayers' money to the extent of twenty-five dollars per day on charges for a school bus, which is occupied by only one student for only a fraction of the mileage. ${ }^{.54}$

It is at a point early in September of 1958 that W.H. Swift appears in the surviving official correspondence pertaining to the matter. The issue, having been, according to Swift, "brought to the Minister's attention in various ways, ${ }^{55}$ had obviously become a concern for the Department. Earlier in September, for a few days, Atlee school had operated in defiance of the division's edict. However, when it was realized that this was an illegal action, the school was again closed, by ministerial order. ${ }^{56}$ After careful consideration Swift dispatched two superintendents, O.P. Larson from Brooks and N.M. Purvis from Taber, to assess the situation and submit a confidential report. ${ }^{57}$ From his correspondence, it is evident that Swift was well aware of the relevant issues surrounding the case, probably due to the fact that he had helped broker a compromise between the two sides the previous year. ${ }^{58}$ After succinctly outlining the substance of the dispute, and carefully giving each side their due, Swift clearly stated the Department of Education's position:

The Department has consistently taken the stand that this is a matter which rests within the jurisdiction of the Medicine Hat School Divisional Board having regard to the provisions of the School Act and that no power resides in the Minister or Department to require the Medicine Hat School Division to reopen the Atlee School supposing it were the view of the Department that this would be the preferable arrangement [sic]. Nevertheless, ... we feel under some obligation to make a serious study of the situation. ${ }^{59}$

On September 23, as a result of the reports submitted by Larson and Purvis, Swift recommended to the Medicine Hat Board that the Atlee School be re-opened. He further recommended that "consultations be entered into with the Atlee people in good time in 1959" if the board had then, "as a result of changed conditions or for other reason, intention to change the situation at Atlee." ${ }^{60}$ The factors by which Swift arrived at this decision were once again concisely outlined:

\footnotetext{
${ }^{51}$ The Calgary Herald, October 3, 1958.

${ }^{52}$ Ibid.

${ }^{53}$ The Medicine Hat News, Oct 23, 1958.

${ }^{54}$ Ibid.

${ }^{55}$ The Minister of Education at the time was A.O. Aalborg. Correspondence from W.H. Swift to Superintendent O.P. Larson and Superintendent N.M. Purvis, September 11, 1958. Cypress Hills Divisional Records, Calgary-Glenbow Archives.

${ }^{56}$ Ibid.

${ }^{57}$ Ibid.

${ }^{58}$ The Medicine Hat News, August 28, 1958. Details of the meeting were also outlined in a circular addressed to All Divisional Board Members from A.T. Shand, Secretary Treasurer, Medicine Hat School Division No. 4., October 30, 1957. Cypress Hills Divisional Records, Calgary-Glenbow Archives.

${ }^{59}$ Correspondence from W.H. Swift to Superintendent O.P. Larson and Superintendent N.M. Purvis, September 11, 1958. Cypress Hills Divisional Records, Calgary-Glenbow Archives.

${ }^{60}$ Correspondence, Swift to the Board of the Medicine Hat School Division No. 4, September 23, 1958.
} 
1. While it is no fault of your board the road is still not improved, this was a factor a year ago and still remains a factor. Admittedly there may be differences of opinion as to whether the road is suitable for a school bus but we think that the Atlee people have some justification for their view that centralization should not be forced until the prospective road work is completed.

2. The inclusion of Atlee has been urged as a necessity to provide enough pupils for a two-room school. Such was perhaps true a year ago but there now seem to be 45 pupils without Atlee which warrants two rooms.

3. We question that a two-room school is sufficiently superior to a one-room school of low enrolment to warrant the forcing of extensive transportation of pupils upon reluctant parents.

4. There will be no significant financial saving, if any, to the division if the Atlee school is closed. ${ }^{61}$

Swift concluded by recognizing that to open the school after all the controversy would be "something of an embarrassment" to the board, but believed that the Department's investigators had "looked into the situation impartially."62

According to an editorial in The Medicine Hat News, "legally the board of School Division No. 4 and Education Minister A.O. Aalborg acted quite properly in ordering that classes in Atlee School cease," because of unauthorized use of property. ${ }^{63}$ The paper went on to point out that:

Morally, however, both the school board and the education department should do considerably more than order the school closed, stand pat on its order that the 15 pupils must travel daily by bus to and from Jenner, 19 miles away, and talk about laying charges against those parents who refuse to let their children ride the bus. Somehow or other, steps should be taken to permit the children to attend the Atlee School legally, at least until there is evidence the road to Jenner has been repaired to the extent the bus runs can be made in safety. ${ }^{64}$

Obviously, Swift chose to act on the moral issue in this case. Still, the Divisional Board would not relent. A few days after receiving Swift's recommendations, notice was sent back to him that the Divisional Board had decided, in spite of the Department's recommendations, that the Atlee School would be closed. In addition, wrote Board Secretary A.T. Shand, the Board had the following comments to offer on Swift's letter. First of all, in the Board's opinion, school bus transportation in many other parts of the Division and throughout the Province would be seriously curtailed if service was only permitted on roads superior to the Jenner-Atlee highway. The Board, the letter continued, did not feel justified in postponing vanning to Jenner for another full year when work is actually underway to improve the road at a cost of twenty thousand dollars. Shand's letter concluded by stating that the Board was more concerned with offering an improved education to the Atlee pupils than with effecting any saving as had been implied by Swift. ${ }^{65}$

The same day, the Atlee parents were informed of the Board's decision in a rather terse communication. The notice read:

At a special meeting of the Divisional Board yesterday, the Board directed that you be notified that under no circumstances is it prepared to re-open the Atlee School. Furthermore, the present school bus service, which has been provided so that your children may attend the Jenner School, is to be discontinued after Friday, October 3, 1958, unless you indicate that you intend to make use of this service. . . . If your children are not in attendance at the Jenner School by October 3, 1958, the Board is recommending to the Minister of Education that the Atlee and Valley Springs School Districts be excluded from this Division. ${ }^{66}$

\footnotetext{
${ }^{61}$ Ibid.

${ }^{62}$ Ibid.

${ }^{63}$ The Medicine Hat News, September 9, 1958.

${ }^{64}$ Ibid.

${ }^{65}$ Correspondence A.T. Shand, Secretary-Treasurer, Medicine Hat School Division No. 4, to The Deputy Minister, Department of Education, September 26, 1958. Cypress Hills Divisional Records, Calgary-Glenbow Archives.

${ }^{66}$ Correspondence from A.T. Shand, Secretary-Treasurer, Medicine Hat School Division No. 4 to All Parents in the Atlee School Attendance Area, September 26, 1958. Cypress Hills Divisional Records, Calgary-Glenbow Archives.
} 
On September 27, The Medicine Hat News roundly criticized the Divisional Board, labelling them as incompetents. The newspaper accused the board of "blindly charging off in the wrong direction over the Atlee school question for the past month." The story went on to describe how the board had refused help in "getting on the right path." It described how Swift had advised them to re-open the Atlee School and that "in a welter of whereases [sic], the board had said no." Thus, the paper went on, "in addition to flying in the face of the people of Atlee - whose servants they are supposed to be - members of the board are now acting against the best advice of the Department of Education." ${ }^{67}$ It further speculated that since the board refused to divulge the exact contents of Swift's letter, it had to be assumed that the board had something to hide. ${ }^{68}$ The editorial concluded by pointing out that:

Now having threatened legal action against the recalcitrant Atlee parents, the board is asking that Atlee be excluded from the School Division. It's about time that something like that happened - the board of School Division No.4 has shown no indication whatsoever that it is competent to deal with the situation. ${ }^{69}$

A final example of official correspondence from the year 1958 seems to effectively end the dispute. In a typically well organized and precise letter, Swift clearly outlined the alternatives available to the Atlee parents. He acknowledged that the parents had been given a deadline by the board for bussing to Jenner and that failure to comply would result in exclusion from Medicine Hat School Division No.4. According to Swift, this would probably involve also the exclusion of the Valley Springs District and also some unaffiliated families that did not reside in any district. The two options, therefore, appeared to be:

1. For attendance at Jenner to be accepted.

2. For the districts to be removed, to elect their own school boards, and to operate their affairs independently. This means reverting to the status which existed before the erection of the divisions. ${ }^{70}$

The letter pointed out that it had been the hope of the Department that the Division would accede to its recommendation. "It's clear, however, that it will not and so the situation as it now stands must be faced." ${ }^{71}$

Swift went on to caution that since operation as an independent district appeared to be the most likely alternative, that "the most careful consideration be given to forcing this step." ${ }^{72} \mathrm{He}$ pointed out that:

It seems to us that if the district is made independent its re-acceptance by the Division would not reasonably be expected if in one, two, three or more years changed circumstances made this desirable. [As well], ... what is the future of school service in your district if:

1. No teacher is available locally?

2. The school population should diminish?

3. High School service is needed?

4. Centralization arrangements become more attractive? ${ }^{73}$

Swift concluded the letter by observing that the Department had attempted to assist the parents of Atlee in getting their school re-opened under the auspices of the Division. This had not been possible. The Department, however, we are still inclined to the view that "for the long term educational advantage of [their] . . district more [was] . . .likely to be gained by staying with the Division than by accepting independent status." ${ }^{74}$

\footnotetext{
${ }^{67}$ Ibid.

${ }^{68}$ Ibid.

${ }^{69}$ Ibid.

${ }^{70}$ Correspondence, Swift to James Walsh, Secretary, Atlee School Division, September 29, 1958. Cypress Hills Divisional Records, Calgary-Glenbow Archives.

${ }^{71}$ Ibid.

${ }^{72}$ Ibid.

${ }^{73}$ Ibid.

${ }^{74}$ Ibid.
} 


\section{CONCLUSION}

On October 4, 1958, a storyline in the Calgary Herald proclaimed: "Parents Win Rural War With School Reopened: Strike Ends; Bus Service Cancelled." The story, calling the Atlee School "the last of the one-room schools", pointed out that it was "strange that the centralization process should be thwarted now, after it [was] . . . almost complete." The Atlee people, the paper pointed out, put up stronger objection than parents and ratepayers elsewhere, and succeeded. The article concluded by speculating on "what would have happened to the centralization process if other parents had been as vigorous in their protest. ${ }^{75}$

While Bill Swift's role in this affair as Deputy Minister was largely the delegation of tasks seemingly arrived at by consensus within the appropriate divisions in the Department of Education, he nevertheless seemed to be the focal point in the Department's communications to the different sides in the dispute. It was Swift who was most often looked upon to provide the correct interpretation of the School Act, and thus clearly articulate the Government's position. According to R.H. McKinnon, Swift was:

Very meticulous, very much concerned with etiquette and the laws and so on. If you needed to do a certain thing, and had to look at the legislation proper, he was the man. He spent all his time as Deputy Minister trying to get the School Act so that it would not need any changes, to perfect it, an almost impossible task because of the way things changed. He was certainly excellent when it came time to figure out what should be the next move. ${ }^{76}$

However, as evidenced by his actions in this dispute, Swift could see that the Atlee parents had legitimate complaints. Even though the Division was well within its rights to enforce bussing to Jenner, there was a moral imperative that had to take precedence in this case. Swift was not so bound by the rules of convention and the School Act that a decision could not be made for the general good of the children of Atlee.

Swift may have been among the last of his kind. By his final years as Deputy Minister, the position had become more and more complex, requiring the delegation of tasks formerly routinely performed by the Deputy Minister. In this light, Swift might be viewed as among the last of the self-made moral exemplars - someone to whom subordinates in the Department could look up to, as Swift did with his predecessor to provide leadership and continuity in the Department of Education, someone whose "character" was beyond question.

As an epilogue, it is of interest to note that, according to an official ministerial order dated April 29, 1965, R.H McKinnon included "the Atlee School District No. 3389 in the Medicine Hat School Division No.4." This order was to take effect on May 3, 1965. ${ }^{77}$ The issue, on a wider scale might be seen as a way of understanding the problems and difficulties involved in a shift, even as late as the mid-1960s, from a rural life built on the strength of local community and co-operative spirit, to a much more urbanized and structured existence. The school where one's child was to be educated was a microcosm of this change.

\footnotetext{
${ }^{75}$ Calgary Herald October 4, 1958,

${ }^{76}$ Personal interview with R.H. McKinnon, January 26, 1998

${ }^{77}$ Ministerial order from R.H. McKinnon to W.H Swift, April 29, 1965. Cypress Hills Divisional Correspondence, Calgary-Glenbow Archives.
} 
NOTES 